\title{
MEMAHAMI GENDER UNTUK MENGATASI KEKERASAN DALAM RUMAH TANGGA
}

Oleh :

Rahmah Marsinah, SH, MM

\begin{abstract}
:
Perbedaan jender pada dasarnya merupakan hal yang biasa atau suatu kewajaran. Sepanjang tidak menimbulkan ketidak adilan jender. Akan tetapi realitas didalam masyarakat menunjukkan bahwa perbedaan jender telah menimbulkan berbagai bentuk ketidak adilan, baik bagi kaum laki-laki dan terutama kaum perempuan. Ketidak adilan jender ini dapat dilihat dalam wujud seperti pemberian beban kerja yang lebih berat kepada kaum perempuan seperti halnya mereka perempuan yang terpaksa harus bekerja diluar rumah karena mereka dituntut harus menyelesaikan tugas dirumah tangga mengingat tugas rumah tangga adalah kewajiban kaum perempuan.
\end{abstract}

\section{PENDAHULUAN}

Banyak penyebab untuk terjadinya kekerasan dalam rumah tangga diantaranya, menyebutkan bahwa laki-laki merupakan sumber konsep yang berbeda dengan perempuan. Laki-laki bersumber pada keberhasilan pekerjaan, persaingan dan kekuasaan, sementara perempuan bersumber pada keberhasilan tujuan pribadi citra fisik di dalam hubungan keluarga. Konsep diri yang muncul dari model sosialisasi ini menyebabkan perempuan tidak berani menghadapi suaminya, sebaliknya si suami merasa mendapatkan kekuasaan penuh terhadap istrinya. ${ }^{1}$

Tindak kekerasan dalam masyarakat sebenarnya bukan suatu hal yang baru. Kekerasan sering dilakukan bersama dengan salah satu bentuk tindak pidana, seperti yang diatur dalam Kitab UndangUndang Hukum Pidana (KUHP) misalnya pencurian dengan kekerasan (Pasal 365 KUHP), perkosaan (Pasal 285 KUHP) dan seterusnya. Tindak pidana tersebut dilakukan dengan kekerasan atau ancaman kekerasan, sedangkan cara bagaimana kekerasan dilakukan atau alat apa yang

${ }^{1}$ Nawal El Saadawi, Perempuan Dalam Budaya Patriarki, (Jogjakarta: Pustaka Pelajar, 2001), hlm. 23 
dipakai masing-masing tergantung pada kasus yang timbul. Perbuatan tersebut dapat menimpa siapa saja, baik laki-laki maupun perempuan.

Berkaitan dengan kejahatan Kekerasan Dalam Rumah Tngga, yang menarik perhatian publik adalah kekerasan yang menimpa kaum perempuan (istri), dimana pelaku dan korban sama-sama berusaha untuk merahasiakan perbuatan tersebut dari pandangan publik, karena hal tersebut masih dianggap sebagai sesuatu yang tabu untuk ditetahui oleh orang lain. ${ }^{2}$

Kekerasan adalah suatu kejahatan, kekerasan yang dilakukan suami terhadap istri atau yang dikenal dengan kekerasan dalam rumah tangga (domestic violance) adalah salah satu bentuk kejahatan terhadap perempuan yang banyak terjadi di masyarakat. Kekerasan domestik dalam rumah tangga yang dimaksud adalah setiap tindakan berdasarkan jenis kelamin, berakibat pada pembunuhan, kesengsaraan dan penderitaan-penderitaan perempuan secara fisik, seksual dan psikologis termasuk ancaman tindakan tertentu, pemaksaan atau perampasan kemerdekaan secara sewenang-wenang baik yang ada di depan umum atau dalam lingkungan pribadi. ${ }^{3}$

Dengan memperhatikan fakta yang terurai di atas nampak bahwa penganiayaan dalam rumah tangga khususnya dalam hal ini penganiayaan yang dilakukan suami terhadap istri menunjukkan sifat kejahatan yang meluas dan berlangsung secara sistematik dan terpola. Artinya, kekerasan dalam rumah tangga (kepada

2 Soeroso, hadiati moerti, Kekerasan Dalam Rumah Tangga, (Jakarta : Sinar Grafika 2010), $h \operatorname{lm} 1$.

3 Ahmad Suaedy, Kekerasan Dalam Perspektif Pesantren, (Jakarta: Grasindo, 2000), hlm . 79. istri), sebetulnya dapat dikategorikan sebagai kejahatan terhadap kemanusiaan dan harus mendapatkan perhatian dan penanganan yang serius oleh negara. Berpijak pada kenyataan tersebut, jelaslah disini bahwa masih banyak perempuan menjadi korban dari tindak kekerasan kemusiaan. ${ }^{4}$

Dari kasus-kasus yang terungkap, tenyata masih banyak korban-korban kekerasan dalam rumah tangga baik terhadap istri ataupun anak, tidak dilaporkan kepada pihak yang berwajib dengan alasan hal tersebut merupakan permasalahan intern keluarga. Secara umum kekerasan dalam rumah tangga dapat terjadi terhadap anak, istri, pembantu atau orang yang menetap dalam rumah tangga tersebut. Bahkan korban kekerasan dalam rumah tangga sering terjadi pada perempuan dan anakanak. Sedangkan yang menjadi pelaku kekerasan adalah suami atau istri atau orang lain yang menetap dalam rumah tangga tersebut.

Permasalahan jender pada dasarnya sudah jadi pembicaraan umum dikalangan masyarakat birokrasi, ilmiah, bahkan dikalangan masyarakat biasa seperti pada tingkat RT, RW maupun Kelurahan. Pemikiran tentang jender ini memang dapat ditangkap sebagai pemahaman umum yang menginginkan adanya suatu perubahan dalam interaksi dan didalam masyarakat berkaitan dengan persamaan hak dan kewajiban antara kaum laki- laki dan perempuan.

Walaupun pembicaraan orang tentang jender sudah merebak setidaknya sekitar 10 tahunan terakhir, namun ternyata apa

${ }^{4}$ Mansour Fakih, Masyarakat Sipil Untuk Transformasi Sosial, pergolakan ideologi LSM indonesia,(Pustaka Pelajar: Yogyakarta, 2004), hlm. 17. 
yang dipahami orang tentang jender masih terjadi kesalah pahaman, terutama halhal yang berkaitan dengan maksud dan konsep jender dalam kaitan upaya Pemberdayaan Kaum Perempuan. Hal ini seperti peristilahan asing lainnya ternyata masih menimbulkan kecurigaan karena secara umum orang belum mengenal secara detail / mendalam tentang konsep sender itu sendiri.

Pada dasarnaya peristilahan jender sering kali dirancukan dengan istilah Jenis Kelamin, dan lebih rancu lagi karena jender diartikan dengan "Jenis Kelamin Perempuan", karena yang dibayangkan orang jender berarti sosok manusia dengan jenis kelamin perempuan. Padahal istilah "jender" bukan hanya menyangkut jenis kelamin perempuan, melainkan juga jenis kelamin laki- laki. Oleh karena itu penting sekali memahami terlebih dahulu perbedaan antara Jenis Kelamin (seks) dan Jender.

\section{JENIS KELAMIN (SEKS) DAN JENDER}

Yang dimaksudkan dengan jenis kelamin (seks) adalah perbedaan biologis hormonal dan patologis antara perempuan dan laki- laki, misalnya lakilaki memiliki penis, testis, dan sperma, sedangkan perempuan mempunyai vagina, payudara, ovum dan rahim.

Dalam hal ini antara laki- laki dan perempuan secara biologis mempunyai perbedaan, dan masing- masing mempunyai keterbatasan dan kelebihan untuk organ biologis itu sendiri. Misalnya perempuan bisa mengandung, melahirkan dan menyusui bayinya, sementara kaum laki- laki bisa memproduksi sperma untuk pembuahan sel telur. Dan untuk dipahami bahwa perbedaan biologis ini merupakan sifat kodrati pemberian Yang Maha Kuasa kepada manusia tanpa bisa di ciptakan ataupun diubah oleh manusia lainnya.

Yang dimaksud dengan Jender adalah suatu konsep yang mengacu pada peranperan dan tanggung jawab laki- laki maupun perempuan sebagai hasil konstruksi sosial yang dapat diubah sesuai dengan perubahan jaman. Dalam hal ini yang perlu diperhatikan adalah sikap, peran dan tanggung jawab, fungsi, hal dan perilaku yang melekat pada diri laki- laki dan perempuan sebagai akibat bentukan budaya atau lingkungan masyarakat tempat manusia itu tumbuh dan dibesarkan.

Sebagai contoh adalah jika ia seorang lakilaki yang digambarkan adalah ia manusia yang kuat, perkasa, berani, rasional dan tegar. Namun sebaliknya bila ia seorang perempuan maka yang digambarkan adalah figur yang gemulai, pemalu, penakut, emosional, rapuh, lembut dan lainnya. Berarti dalam hal in perbedaan sifat, sikap dan perilaku yang dianggap khas perempuan atau khas laki- laki (Feminitas dan Maskulinitas) hal ini merupakan hasil pembelajaran melalui proses, sosialisasi dari suatu waktu ke waktu dimana orang itu tumbuh dan berkembang. Berati berkaitan dengan Feminitas dan Maskulinitas bukanlah hal yang kodrati, melainkan hal yang dapat berubah dari waktu kewaktu atau tempat yang berbeda.

Didalam masyarakat ternyata selalu ada pembagian kerja anggota masyarakat dilihat dari perbedaan seksualnya secara laki- laki atau secara perempuan yang biasa dikenal dengan nama "Peran Jender". Mengingat secara biologis 
perempuan mempunyai organ reproduksi untuk hamil, melahirkan, dan menyusui, lalu berkembanglah pengertian peran jender bahwa peran utama perempuan adalah sebagai perawat atau pendidik anak. Dan konsekuensi logis dari peran tersebut adalah bahwa pekerjaan di rumah tangga merupakan tugas dan kewajiban pokok kaum perempuan. Dari sini kemudian muncul berbagai masalah bagi perempuan yang pada akhirnya hal ini disebut sebagai "Ketidak adilan Jender"

\section{KETIDAK ADILAN JENDER}

Perbedaan jender pada dasarnya merupakan hal yang biasa atau suatu kewajaran. Sepanjang tidak menimbulkan ketidak adilan jender. Akan tetapi realitas didalam masyarakat menunjukkan bahwa perbedaan jender telah menimbulkan berbagai bentuk ketidak adilan, baik bagi kaum laki- laki dan terutama kaum perempuan.

Ketidak adilan jender ini dapat dilihat dalam wujud seperti pemberian beban kerja yang lebih berat kepada kaum perempuan seperti halnya mereka perempuan yang terpaksa harus bekerja diluar rumah karena mereka dituntut harus menyelesaikan tugas dirumah tangga mengingat tugas rumah tangga adalah kewajiban kaum perempuan.

Beberapa bentuk ketidak adilan jender yang sering ditemui dalam masyarakat antara lain :

1. Perlakuan kekerasan (violence) yang meliputi kekerasan didalam rumah tangga ( ranah domestic) dan kekerasan diluar rumah tangga (ranah public). Bila hal itu terjadi dalam rumah tangga biasanya dapat dilihat dalam wujud penganiayaan fisik maupun psikhis, pemaksaan hubungan seksual, pelecehan atau suami berselingkuh. Sedangkan diluar rumah tangga biasa dalam wujud pelecehan terhadap perempuan.

2. Marginalisasi atau pemiskinan perempuan dalam bidang ekonomi. Proses pemiskinan ini disebabkan banyak pekerjaan perempuan yang dinilai lebih rendah kualitasnya dari pada pekerjaan laki- laki. Oleh karena itu upah bagi prempuan umumnya dinilai lebih rendah dari upah kaum laki- laki. Contohnya adalah yang biasa terjadi di industri garmen, perempuan yang memasang kancing tenaganya dibayar amat murah dibandingkan dengan tenaga kuli yang mengakut barang. Padahal untuk memasang kancing ternyata memerlukan ketelitian dan kecermatan / konsentrasi.

3. Anggapan bahwa perempuan tidak penting, atau perempuan dianggap sebagai pelengkap dari kepentingan laki- laki. Hal ini bisa terjadi didalam rumah tangga dan juga didalam masyarakat umum. Pendapat masyarakat umum masih beranggapan bahwa perempuan umumnya tidak rasional, emosional, oleh karena itu perempuan tidak layak untuk menjadi pemimpin.

4. Hal - hal lain yang sudah jadi anggapan mutlak didalam masyarakat seperti pernyataan "Perempuan tidak perlu sekolah tinggi- tinggi, nanti juga kedapur larinya", "Perempuan sebagai makhluk penggoda". Pernyataan ini ternyata sangat merugikan kaum perempuan, terlebih lagi bila terjadi kasus pemerkosaan, maka perempuan langsung jadi tudingan sebagai 
penyebabnya. Padahal disisi lain justru perempuanlah yang menjadi korban.

\section{BUDAYA YANG MASIH BERPERAN}

Sejarah perbedaan jender antara laki- laki dan perempuan terjadi melalui proses yang panjang, dan ini merupakan hasil kreasi masyarakat yang banyak dipengaruhi oleh berbagai faktor yang berkembang dimasyarakat seperti tradisi, adat istiadat, corak budaya, ajaran agama dan bahkan masalah kebijakan yang dibuat oleh Negara / pemerintah. Untuk itu ada beberapa contoh adat budaya yang telah dibakukan seperti menganggap perempuan sebagai "Konco WIngking". Hal ini menggambarkan bahwa posisi perempuan memang selalu berada di belakang dan dibatasi oleh dinding yang tebal, oleh karena itu tidak layak untuk tampil kedepan.

Seringnya kaum perempuan belum bisa menhargai hasil pekerjaannya sendiri. $\mathrm{Hal}$ ini biasanya kaum perempuan masih sering untuk tidak menyatakan berapa penghasilannya untuk menunjang kehidupan rumah tangga, karena menjawab dengan malu- malu "yah cukup untuk membeli bedak dan lipstick aja". Padahal disatu sisi sebenarnya ia justru menjadi tulang punggung keluarga.

Pernyataan dalam masyarakat adat yang mengatakan bahwa untuk perempuan itu "Suargo nunut, Neroko katut". Pernyataan ini mengingat budaya keagamaan yang dianut masyarakat kita adalah budaya agama Islam, sehingga bila suaminya Alim Ulama, yang bisa membawakan doa- doa dan suasana keIslaman dalam rumah tangga, maka secara otomatis jalan menuju ke Sorga bagi istri sudah dirintis terlebih dahulu oleh pihak suami. Akan tetapi di lain situasi bila suami tidak dapat membawakan hal- hal yang baik dalam rumah tangga, maka otomatis istri akan terbawa juga ke Neraka. Budaya yang melekat seperti ini menunjukkan bagaimana situasi yang rapuh yang melekat pada diri kaum perempuan dalam rumah tangga, dan ketergantungan yang mutlak seorang istri kepada suaminya.

Fakta dalam masyarakat ternyata masih memperlihatkan bahwa pekerjaan rumah tangga seperti menyapu, mengepel, memasak dan lainnya dianggap tabu untuk dilakukan oleh kaum suami, sehingga bila terjadi suatu kondisi dimana istri terpaksa harus mengambil alih tugas sebagai pencari nafkah untuk rumah tangga, maka pada situasi ini beban pekerjaan istri menjadi berlipat ganda. Hal ini terjadi karena bila istri pulang yang didapatkan dirumah adalah kondisi yang berantakan, kotor, bertumpuknya pakaian yang harus dicuci dan lainnya, karena suami merasa tabu untuk melakukan pekerjaan rumah tangga tersebut.

Budaya adat yang umumnya mengutamakan anak laki- laki ternyata masih berpengaruh dalam masyarakat adat dinegara kita yang menganut system "Patriarchat" / system Kebapakan. Hal ini terjadi bila dalam rumah tangga terdapat anak laki- laki dan perempuan, maka yang diutamakan untuk menempuh perdidikan lebih tinggi adalah anak laki- laki, dengan alasan bahwa anak laki tersebut sebagai pewaris utama dan penerus generasi.

\section{PENUTUP}

Sebagai suatu kenyataan yang perlu dipahami bersama dalam hal pengertian dan pemahaman tentang jender berikut pengaruh ketidak adilan jender adalah perlu adanya saling menghargai. Dari sisi Hak Asasi Manusia sebagaimana 
tercantum dalam Undang - undang No. 39 tahun 1999 tentang Hak Asasi Manusia menyatakan bahwa Hak Asasi Manusia adalah "Seperangkat hak yang melekat pada hakikat keberadaan manusia sebagai makhluk Tuhan Yang Maha Esa dan merupakan anugerah-Nya yang wajib di hormati, dijunjung tinggi dan dilindungi oleh Negara, hukum, pemerintah dan setiap orang demi kehormatan serta perlindungan harkat dan martabat manusia".

Mengacu pada pemahaman tentang hak asasi manusia tersebut pada dasarnya sekaligus kita juga memenuhi kewajiban asasi kita sebagai sesama manusia. Dalam hal ini bila permasalahan kita kaitkan dengan situasi timbulnya "Ketidak Adilan Jender" dalam masyarakat, maka disini terlihat bahwa hal yang dikatakan sebagai suatu kondisi ketidak adilan jender terjadi bila ternyata disana sudah tidak ada lagi saling menghargai. Istilah yang dapat digunakan dalam hal ini adalah "Tepo Sliro" dalam bahasa Jawa, atau "Lamak di awak Katuju di Urang" untuk adat Minang.

\section{DAFTAR PUSTAKA}

1. Ahmad Suaedy, Kekerasan Dalam Perspektif Pesantren, (Jakarta: Grasindo, 2000)

2. Nawal El Saadawi, Perempuan Dalam Budaya Patriarki, (Jogjakarta: Pustaka Pelajar, 2001), hlm. 23

3. Mansour Fakih, Masyarakat Sipil Untuk Transformasi Sosial, pergolakan ideologi LSM indonesia,(Pustaka Pelajar: Yogyakarta, 2004).

4. Soeroso, hadiati moerti, Kekerasan Dalam Rumah Tangga, (Jakarta : Sinar Grafika 2010), hlm 1.
5. Tim Pemberdayaan Perempuan Bidang Agama, Departemen Agama RI; Keadilan dan Kesetaraan Jender Jakarta; 2001

6. Undang - Undang No. 39 tahun 1999 Tentang Hak Asasi Manusia;

7. Pengarus Utamaan Jender; Departemen Kehakiman dan Haka Asasi Manusia RI; Jakarta, 2004 